\title{
"Performance evaluation using the CAMELS model: A comparative study of local commercial banks in Qatar and Kuwait"
}

\begin{tabular}{ll} 
AUTHORS & $\begin{array}{l}\text { Rawan Abuzarqa (iD } \\
\text { Tibor Tarnóczi (iD }\end{array}$ \\
& $\begin{array}{l}\text { Rawan Abuzarqa and Tibor Tarnóczi (2021). Performance evaluation using the } \\
\text { CAMELS model: A comparative study of local commercial banks in Qatar and } \\
\text { Kuwait. Banks and Bank Systems, 16(3), 152-165. } \\
\text { doi:10.21511/bbs.16(3).2021.14 }\end{array}$ \\
\hline ARTICLE INFO & http://dx.doi.org/10.21511/bbs.16(3).2021.14 \\
\hline DOI & Monday, 04 October 2021 \\
\hline RELEASED ON & Thursday, 18 March 2021 \\
\hline RECEIVED ON & Sunday, 01 August 2021 \\
\hline ACCEPTED ON & $\begin{array}{l}\text { (co) EY } \\
\text { This work is licensed under a Creative Commons Attribution } 4.0 \text { International }\end{array}$ \\
\hline LICENSE & License \\
\hline JOURNAL & "Banks and Bank Systems" \\
\hline ISSN PRINT & $1816-7403$ \\
\hline ISSN ONLINE & $1991-7074$ \\
\hline PUBLISHER & LLC “Consulting Publishing Company "Business Perspectives" \\
\hline FOUNDER & LLC “Consulting Publishing Company "Business Perspectives"
\end{tabular}

NUMBER OF REFERENCES

27

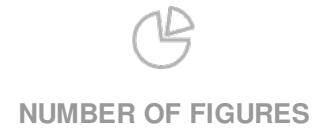

0
NUMBER OF TABLES

10

(C) The author(s) 2021. This publication is an open access article. 


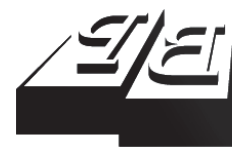

\section{BUSINESS PERSPECTIVES}

(O)

LLC "CPC "Business Perspectives" Hryhorii Skovoroda lane, 10, Sumy, 40022, Ukraine www.businessperspectives.org
Received on: $18^{\text {th }}$ of March, 2021 Accepted on: $1^{\text {st }}$ of August, 2021 Published on: $4^{\text {th }}$ of October, 2021

(c) Rawan Abuzarqa, Tibor Tarnoczi, 2021

Rawan Abuzarqa, Ph.D. Candidate, Károly Ihrig Doctoral School of Management and Business, University of Debrecen, Hungary. (Corresponding author)

Tibor Tarnoczi, Associate Professor, Institute of Accounting and Finance, Faculty of Economics and Business, University of Debrecen, Hungary.
This is an Open Access article, distributed under the terms of the Creative Commons Attribution 4.0 International license, which permits unrestricted re-use, distribution, and reproduction in any medium, provided the original work is properly cited.

Conflict of interest statement: Author(s) reported no conflict of interest

\section{PERFORMANCE EVALUATION USING THE CAMELS MODEL: A COMPARATIVE STUDY OF LOCAL COMMERCIAL BANKS IN QATAR AND KUWAIT}

\begin{abstract}
Nowadays, the banking system is undergoing significant changes. Digitalization that appears in Industry 4.0 also pioneers in the banking system, so we can also talk about Bank 4.0 as a new development direction. In this shift in the digital age, it becomes even more critical to examine the performance of banks. The case study approach was based on an attempt to diagnose the performance of a sample of local commercial banks in Qatar and Kuwait based on their financial statements for the period 2013 2017, and approve the existing accounting data as sources for the financial analysis process, by using essential financial analysis tools such as financial ratios. The output of the analysis was used to measure performance. All this is applicable when using the CAMELS rating model to evaluate the financial performance of the banking sector. The results show statistically significant differences between countries for four factors (Asset quality, Management efficiency, Earnings quality and Sensitivity) and none for the remaining two (Capital adequacy and Liquidity management) because the significant level is higher than $5 \%$. However, the two factors with no significant differences are vital to the prudent operation of banks, mainly that Qatari banks perform better than Kuwaiti banks.
\end{abstract}

Keywords

performance analysis, CAMELS approach, comparative analysis

JEL Classification G21, G32

\section{INTRODUCTION}

Banks are considered the main engine of the economy and social life. The banking sector is a crucial element in strengthening confidence in state policies and supporting economic interests. They play an essential role in linking financial surplus units (savers) with deficit units (investors) (Chandani et al., 2014).

Recently, the banking sector has seen increased domestic and foreign competition in the financial services market. Banks need to be supervised and monitored to maintain their financial position soundness and achieve a strong banking sector. Banks should protect depositors and investors' interests and ensure the proper implementation of the state's monetary policy and healthy financing of long- and short-term investments to contribute effectively to the development and prosperity of the national economy (Dincer et al., 2011). Based on this, banks are seen as the actual mirror, reflecting the real face of states' economies. Therefore, it is transparent that any risk the sector faces can affect all system elements without exception. This situation encouraged researchers and specialists in 
finance and banking to seek and develop financial models that can detect risks that create weaknesses in the operational, administrative and financial transactions and reduce the severity of threats in the sector (Thagunna \& Poudel, 2013).

As a result of the uncertain environment faced by banking sectors in both developed and developing countries, various types of risks threaten the performance of the banking sector. There are many analytical, statistical, and other quantitative tools used to measure performance efficiency. Given these measurement tools, the CAMELS framework is considered one of the most widely used in this field. It evaluates the overall position of a bank and identifies its strengths and weaknesses. The CAMELS model is defined as a holistic assessment tool used by supervisory parties to evaluate the financial stability of banking institutions (Rose \& Hudgins, 2010). This model includes six factors: Capital adequacy, Asset quality, Management efficiency, Bank earnings, Liquidity management, and Sensitivity to market risk. The model name reflects the first letter of each of the previous factors.

The basic aim of the study is to determine the ranking of banks by country using the CAMELS model and compare banks within and between countries using the indicators of the CAMELS model. The study sought answers to the following questions:

1. What is the effect of the twelve selected financial ratios, which represent the components of the CAMELS model, on the performance of commercial banks in Qatar and Kuwait?

2. What is the level of financial performance of Qatari commercial banks compared to the financial performance of Kuwaiti commercial banks?

\section{LITERATURE REVIEW AND RESEARCH HYPOTHESES}

\subsection{Using CAMELS analysis in evaluating the performance of the banking sector}

Ghazavi and Bayraktar (2018) investigated six Turkish banks using the CAMELS method to measure banking performances for ten years. In none of the banks, they could observe higher performance than in others. CAMELS ratios have been quite close to each other, mainly in 2016. The CAMELS rating shows that organizational ratings and financial indicator trends comply with norms and international standards.

The CAMEL rating approach is deemed a vital tool to characterize the financial solidity and feebleness of banks. CAMEL taxonomies have been used to measure the financial performance of banks, and it is considered an effective and predicting tool of bank failures (Barker \& Holdsworth, 1993).
Saikrishna and Varghese (2020) tested the performance of two banks in India, the SBI and HDFC banks, based on the CAMELS rating. The study showed that SBI had significant liquidity ratios. At the same time, HDFC had superior performance ratios of capital adequacy, asset quality, management efficiency, and earnings quality. The result revealed that the private sector bank was at the top of the classification considering its transactions. Likewise, Bodla and Verma (2006) used the CAMELS model to assess the performance of SBI and ICIC Indian banks. Their results showed that capital adequacy was better at the SBI, while ICIC reached better asset quality, earnings quality and management quality. The liquidity position does not have a significant positive relationship in any of the banks.

Yüksel et al. (2015) examined the relationship between CAMELS ratios and credit classifications шт Turkish banks for ten years. The study explained that Asset quality, Management quality, and Sensitivity to market risk positively affect credit ratings. At the same time, the ratios related to Capital adequacy and Earnings are not effective. 
Barr et al. (2002) noted that banks could measure their financial performances with CAMELS classification by analyzing various information collected from the financial statements, providing an accurate and constitutive tool for regulators and experts.

Baral (2005) revealed that joint venture banks are more trustworthy than commercial banks, but they are not ready to manage large size shocks compared to their financial position.

Kumar and Sharma (2014) analyzed the financial performance of eight banks using the CAMELS approach in six years. They collected the financial information from the banks' annual reports.

Nanthini and Shanmugam (2020) measured banks' financial performance in India's public and private sectors for five years using the CAMELS method. They observed that different performances were recorded for each bank regarding the CAMELS ratios. They concluded that Capital adequacy, Asset quality, and Management quality factors were at the top in the private banking sector.

Suresh and Bardastani (2016) conducted a comparative study to evaluate the performance of conventional and Islamic banks using the CAMELS model in the Kingdom of Bahrain. They reported that conventional banks are much more profitable and efficient in their institutional factors than Islamic banks.

Echekoba et al. (2014) investigated the effect of Nigerian banks on profitability using the CAMELS approach for ten years. The study revealed that one factor, liquidity, had a positive impact on profitability. In contrast, the other four factors, asset quality, management efficiency, capital adequacy, and earnings, did not affect profitability. Proposals were made to them to achieve adequate liquidity in order to gain client trust and improve profitability.

Venkatesh and Suresh (2014) used the CAMELS approach to analyze the financial efficiency of commercial banks in the Kingdom of Bahrain. The results showed that the National Bank of Bahrain, owned by the government, achieved the highest efficiency than other banks in the market.
Joshi et al. (2015) examined forty-two commercial banks in India using the CAMELS model for five years (2010-2014). Their results revealed the first ranking of YES bank.

In Romania, commercial banks were tested using the CAMELS approach to analyze their financial soundness. The banks' strengths and weaknesses were analyzed, and guidelines were proposed to increase their safety (Roman et al., 2013).

Nguyen et al. (2020) revealed that CAMELS model components - Capital adequacy, Asset quality, Liquidity and Management efficiency - affect the performance of commercial banks in Vietnam.

Gasbarro et al. (2002) examined banks in Indonesia that provided specific data to control the financial soundness variability. The results revealed that four out of the five CAMELS correlate with the financial soundness of Indonesian banks.

Altan et al. (2014) examined the performance of public and private banks using the CAMELS model. Their results show that Ziraat bank ranked first, while Tekstil Bank was the last. Also, by comparing the types of banks, significant differences were found between public and private Turkish banks.

\subsection{The banking sector in Qatar}

Qatar's banking sector ranks third among the Arab banking sectors in terms of the volume of assets that exceeded USD 276 billion by the end of 2014. Despite the sharp decline in oil prices, it has maintained the strength of its financial position (Union of Arab Banks, 2020). Eighteen banks operate in Qatar, including eleven domestic banks, five foreign banks, and two Arabic banks. The Qatari domestic banking sector consists of 7 conventional banks and 4 Islamic banks. It is worth noting that 10 Qatari banks entered the list of the 100 largest Arab banks according to the assets for the year 2015, as these banks were managing assets of about USD 319.3 billion, which constitutes about $11.3 \%$ of the assets of the largest 100 Arab banks (Qatar Central Bank, 2020).

The State of Qatar has a strong economy based on huge financial foundations and high-level sovereign reserves, in light of its high per capita GDP, 
which is the highest in the world, exceeding one hundred thousand dollars in 2019, in addition to the fact that Qatar is the third country in terms of natural gas reserves. Globally, in parallel, it is the largest exporter of liquefied natural gas in the world (IMF, 2019).

According to Abdul-Wahab and Haron (2017), the strength and durability of banks operating in the Qatari market have worked to attract more Qatari, Arab and foreign investments and capital as well, and all this is in the interest of the sector and confirms the strength of the Qatari banking system, which has become highly trusted by local and foreign investors. On the other hand, the Qatar Central Bank has adopted a fixed exchange rate policy between the Qatari riyal and the US dollar since July 2001 at 3.64 riyals/dollar. This policy is the cornerstone of its monetary policy, and it has proven highly credible.

\subsection{The banking sector in Kuwait}

Twenty-three banks are currently operating in Kuwait, including two governmental banks and twenty-three private banks. The latter include local, joint and foreign banks. The total number of local Kuwaiti banks' internal branches reached 353 (ABA, 2019). The Kuwait banking sector represents the second-largest economic sector in the country after oil exploitation. Kuwaiti banks make significant contributions to the national economy, have provided a high added value over the years and have contributed significantly to GDP growth.

Kuwaiti banks are the external interface of the country through their branches in many countries around the world. Over $50 \%$ of the workforce is working in Kuwait private sector banks. The Kuwaiti banking sector is also an economic sector that uses the most trained human resources and top-level technology (Union of Arab Banks, 2020).

Kuwait has the highest rate of using financial services compared to other countries in the region, as $86.8 \%$ of the population above 15 years has an account in a financial institution. At the gender level, $92.7 \%$ of males and $72.8 \%$ of females have bank accounts (Union of Arab Banks, 2020). The high rate of using financial services in Kuwait comes from the continuous efforts of the Central Bank of Kuwait and other banks.

The banks should have facilitated and improved their tools to access their services for all sectors and the society to encourage banks to increase their branch network, present innovative savings products, facilitate access to credit, and offer modern payment methods (ABA, 2019). The Kuwaiti banking sector is one of the strongest in the Middle East due to the boost of the financial profile, supporting methods and techniques with few foreign banks' competitors. The protection and support by the Central bank of Kuwait protected Kuwaiti banks from the competition of foreign banks. The Kuwaiti banking sector has developed rapidly, and competition, diversification, and innovation increase profitability (Abdmoulah \& Laabas, 2012).

\subsection{Research aims}

By using the CAMELS banking evaluation system, the study aims to encourage banks operating in Kuwait, Qatar and many other countries to identify and measure the risks related to their activities. This analysis contributes to determining the performance of the banks and the degree of their classification. On the other hand, this study fills the lack in research related to evaluating the financial performance of banks operating in Kuwait and Qatar. The results of this study will be a qualitative addition that commercial banks can benefit from.

The CAMELS model was used to analyze banks, and the analysis of variance was used for comparison. The following hypotheses were formulated to perform the analysis:

1. Statistically significant differences between the countries can be determined for all financial ratios.

2. Statistically significant differences between the two countries can be determined based on CAMELS factors.

3. Based on the analysis performed, obvious differences can be identified for banks of the two countries. 


\section{DATA AND METHODS}

\subsection{Research database}

The financial data were collected from annual audited financial statements of the selected banks of both countries. The banks' balance sheets and income statements involved in the study were downloaded from the banks' websites. The local commercial banks selected for the analysis are presented in Table 1, which shows the selected banks, including six local commercial banks from Qatar and five local commercial banks from Kuwait. The examination period of the study was between 2013-2017. The study mainly investigates locally owned commercial banks, while foreign commercial banks and Islamic banks were excluded.

Table 1. Sample of the selected banks

\begin{tabular}{|c|c|c|c|}
\hline \multicolumn{2}{|l|}{ Qatar } & \multicolumn{2}{|l|}{ Kuwait } \\
\hline Bank Name & Code & Bank Name & Code \\
\hline Qatar National Bank & QNB & $\begin{array}{c}\text { National Bank of } \\
\text { Kuwait }\end{array}$ & NBK \\
\hline Doha Bank & Doha B & $\begin{array}{c}\text { Commercial Bank of } \\
\text { Kuwait }\end{array}$ & CBK \\
\hline Alkhaliji Bank & KHLIJI B & Gulf Bank & GULF B \\
\hline $\begin{array}{l}\text { Commercial Bank of } \\
\text { Qatar }\end{array}$ & $\begin{array}{l}\text { Com } \\
\text { Bank }\end{array}$ & Al-Ahli Bank of Kuwait & $\begin{array}{l}\text { ABK } \\
\text { Bank }\end{array}$ \\
\hline $\begin{array}{l}\text { Al-Ahli Bank of } \\
\text { Qatar. }\end{array}$ & $\begin{array}{l}\mathrm{ABQ} \\
\text { Bank }\end{array}$ & Burgan Bank & BURG B \\
\hline $\begin{array}{l}\text { International Bank } \\
\text { of Qatar }\end{array}$ & $\begin{array}{c}\text { IBQ } \\
\text { Bank }\end{array}$ & - & \\
\hline
\end{tabular}

\subsection{Research methods}

The CAMELS model and its related factors were used to evaluate banks' performance in Qatar and Kuwait. The banks were analyzed using two financial ratios per factor, using a total of twelve ratios. These ratios were used to classify banks' ranking and determine the level of their performance.

Single-variate analysis of variance (ANOVA) was applied to compare multiple entities based on one factor. Multivariate analysis of variance (MANOVA) is needed if the entities examined are compared according to multi factors. ANOVA was used to compare individual financial indicators between countries. ANOVA was used to determine whether there was a statistically significant difference between the two countries for each
CAMELS ratio. MANOVA was used to examine the CAMELS factors, where the two indicators in the factors were examined together.

The 12 financial indicators used for the analysis were determined based on similar analyses in the literature. For each CAMELS factor, two financial ratios were selected. The ratios selected for each factor and their abbreviations are shown in Table 2.

Table 2. CAMELS factors and measurement ratios

Source: Authors' elaboration based on the literature.

\begin{tabular}{|c|c|c|c|}
\hline No. & $\begin{array}{l}\text { CAMELS } \\
\text { factors }\end{array}$ & Ratios & $\begin{array}{c}\text { Formula and abbreviation } \\
\text { of ratios }\end{array}$ \\
\hline \multirow{2}{*}{1} & \multirow{2}{*}{$\begin{array}{c}\text { Capital } \\
\text { adequacy (C) }\end{array}$} & 1 & $\begin{array}{l}\text { Total Equity to Total Assets (TE } \\
\qquad / \mathrm{TA})\end{array}$ \\
\hline & & 2 & $\begin{array}{l}\text { Equity to Total Liabilities (EQ } \\
\qquad / \mathrm{TL})\end{array}$ \\
\hline \multirow{2}{*}{2} & \multirow{2}{*}{$\begin{array}{l}\text { Asset quality } \\
\text { (A) }\end{array}$} & 3 & $\begin{array}{l}\text { Total Investment to Total Assets } \\
\text { (TINV / TA) }\end{array}$ \\
\hline & & 4 & $\begin{array}{l}\text { Fixed Assets to Total Assets (FA } \\
\qquad / \text { TA) }\end{array}$ \\
\hline \multirow[b]{2}{*}{3} & \multirow{2}{*}{$\begin{array}{l}\text { Management } \\
\text { quality(M) }\end{array}$} & 5 & Net Profit to Staff Cost (NP / SC) \\
\hline & & 6 & $\begin{array}{l}\text { Net Interest Income to Net profit } \\
\text { (NII / NP) }\end{array}$ \\
\hline \multirow{2}{*}{4} & \multirow{2}{*}{ Earnings (E) } & 7 & Net Profit on Assets (ROA) \\
\hline & & 8 & Net Profit on Equity (ROE) \\
\hline \multirow{2}{*}{5} & \multirow{2}{*}{ Liquidity (L) } & 9 & $\begin{array}{l}\text { Loans to Due to the bank (Loans } \\
\text { / Due bank) }\end{array}$ \\
\hline & & 10 & $\begin{array}{c}\text { Cash \& cash equivalents to Total } \\
\text { Assets (Cash / TA) }\end{array}$ \\
\hline \multirow{2}{*}{6} & \multirow{2}{*}{ Sensitivity (S) } & 11 & $\begin{array}{l}\text { Net Interest Income to Total } \\
\text { Assets (NII / TA) }\end{array}$ \\
\hline & & 12 & $\begin{array}{c}\text { Total Reserves to Total Assets } \\
\text { (TR/TA) }\end{array}$ \\
\hline
\end{tabular}

\section{RESULTS AND DISCUSSION}

\subsection{Ranking banks using the Capital adequacy factor}

The Capital adequacy factor (Table 3) refers to banks' financial strength and ability to hold funds commensurate with the risks faced. The following two financial ratios were chosen to measure it: Total equity to Total assets and Equity to Total liability. The yearly average of the ratios was used to rank the banks. The ranking numbers of the ratio were averaged to rank the banks of a country by the given factor. This procedure was followed for all six factors. 
The higher-ranking number indicates better financial health in Table 3. Given the first ratio (Total equity to Total assets), Qatar's banks can be classified into four groups:

1) Com Bank and Doha Bank;

2) ABQ Bank and IBQ Bank;

3) ALKHALIJI Bank;

4) QN bank.

There is about a one percentage point difference in the case of the first three groups of banks. However, the QN Bank (10.65\%) having the last place differs by about four percentage points from Doha Bank, which is first (14.94\%). The Kuwaiti banks' performance shows a similar tendency in Qatar, while Qatar's ratios have lower values. It can be stated that the total range (maximum value - minimum value) expressed as a percentage of the maximum values differs only slightly (Qatar: $28.71 \%$; Kuwait: $30.17 \%)$. Table 3 shows that Kuwaiti banks perform worse than Qatari ones, as the difference between the two countries' averages for this indicator is $0.8 \%$ in favour of Qatar. However, the last row of Table 3 shows that this difference is not statistically significant, as the significance level of the $\mathrm{t}$-test $(9.03 \%)$ is higher than $5 \%$.
In the second ratio (Equity to Total liabilities), Table 3 shows higher differences among Qatar's banks than were shown in the case of the first ratio. The values of the second ratio value had higher values. The ALKHALIJI Bank has the highest ratio value, almost three times more than the lowest (QN Bank). The maximum and minimum value range is $27.71 \%$, which is $63.65 \%$ of the maximum value. It can be hypothesized that the outstanding ratio value of ALKHALIJI Bank causes a big difference.

However, the ratio value of Kuwait's banks does not have such big differences as Qatar banks. The total range for Kuwaiti banks is only $5.67 \%$, which is $33.73 \%$ of the maximum value, and this is almost half the Qatar value. There seems to be a more significant difference between Qatari and Kuwaiti banks, which seems to be supported by the country's average differences (4.38\%). After all, it can also be seen that ANOVA does not show a statistically significant difference between the two countries despite the more considerable difference in countries' averages.

When assessing the Capital adequacy factor, it can be stated that the examined countries do not differ statistically significantly for any of the indicators. It can be assumed that banks pay increased attention to capital adequacy in both countries.

Table 3. Average ratios of years and rankings in the case of the Capital adequacy factor in selected banks

\begin{tabular}{|c|c|c|c|c|c|c|}
\hline \multirow[b]{2}{*}{ Banks } & \multicolumn{6}{|c|}{ Capital adequacy } \\
\hline & TE/TA & Rankings & EQ/TL & Rankings & $\begin{array}{l}\text { Average } \\
\text { rankings }\end{array}$ & $\begin{array}{l}\text { Ranking } \\
\text { of factor }\end{array}$ \\
\hline \multicolumn{7}{|c|}{ Qatar } \\
\hline QN Bank & $10.65 \%$ & 6 & $12.40 \%$ & 6 & 6.0 & 6 \\
\hline Com Bank & $14.82 \%$ & 2 & $17.36 \%$ & 3 & 2.5 & 2 \\
\hline Doha Bank & $14.94 \%$ & 1 & $18.57 \%$ & 2 & 1.5 & 1 \\
\hline ABQ Bank & $13.39 \%$ & 4 & $15.47 \%$ & 5 & 4.5 & 5 \\
\hline IBQ Bank & $13.95 \%$ & 3 & $16.43 \%$ & 4 & 3.5 & 3 \\
\hline ALKHALIJI Bank & $12.28 \%$ & 5 & $34.11 \%$ & 1 & 4.0 & 4 \\
\hline Average & $13.55 \%$ & - & $19.06 \%$ & - & - & - \\
\hline \multicolumn{7}{|c|}{ Kuwait } \\
\hline NBK Bank & $13.80 \%$ & 3 & $16.02 \%$ & 3 & 3.0 & 3 \\
\hline CBK Bank & $14.26 \%$ & 2 & $16.64 \%$ & 2 & 2.0 & 2 \\
\hline GULF Bank & $10.02 \%$ & 5 & $11.14 \%$ & 5 & 5.0 & 5 \\
\hline BURGAN Bank & $11.32 \%$ & 4 & $12.79 \%$ & 4 & 4.0 & 4 \\
\hline ABK Bank & $14.35 \%$ & 1 & $16.81 \%$ & 1 & 1.0 & 1 \\
\hline Average & $12.75 \%$ & - & $14.68 \%$ & - & - & - \\
\hline Sign. level of ANOVA & $9.03 \%$ & - & $16.83 \%$ & - & - & - \\
\hline
\end{tabular}




\subsection{Ranking banks using the Asset quality factor}

Table 4 refers to the assets' ability to achieve the revenues necessary to face risks associated with loans and investment portfolios. The assets' quality is particularly important in this evaluation model as the bank's activities connected to the asset side play an essential role in achieving revenues. The Total investment to Total assets and Fixed assets to Total assets ratios were used to measure this factor.

Table 4 shows that TINV / TA ratios of Qatari banks are balanced except ALKHALIJI Bank that has a value almost twice as much as others. Comparing the banks of the two countries, one can see big differences among ratio values. The average value of the TINV / TA ratio relating to Kuwaiti banks is less than $50 \%$ of Qatari bank values. Given the above, it can be concluded that Qatari banks performed better in the case of the first variable. A statistically significant difference, which has a significant level of less than $0.1 \%$, also strengthened the latter statement. Presumably, Qatari banks make much higher investments against their total assets than Kuwaiti banks.

The цFixed assets to Total assets ratio values are low in both countries, meaning that the fixed assets do not play an essential role in the bank asset structure. The two countries' ratio values are very similar, and there is no big difference between the country averages. Comparing the two countries based on the FA / TA indicator shows no statistically significant difference between the two countries' banks. Still, the significance level is barely above the 5\% threshold limit (5.89\%).

As a result of the statistical test, it can be stated that there is a significant difference between the two countries in the case of the Asset quality factor.

\subsection{Ranking banks using the Management efficiency factor}

Management efficiency can help adjudge the banks' success, which plays a significant role in driving the governance system to reply rapidly to a very active and rapidly varying environment.

Table 5 shows that both ratios have an outlier value NP / Staff cost in Qatari banks: QN Bank; NII / PROF: Com Bank). Overall, there are big differences in the Net profit to Employee cost ratio in the banks of both countries. Based on the table, it can be assumed that employees can produce a profit more efficiently in Qatari banks than in Kuwaiti banks. When comparing these ratios of the two countries, one can see that Qatari banks' ratios

Table 4. Average ratios of years and rankings in the case of the Asset quality factor at selected banks

\begin{tabular}{|c|c|c|c|c|c|c|}
\hline \multirow{2}{*}{ Banks } & \multicolumn{6}{|c|}{ Asset quality } \\
\hline & TINV/TA & Rank & FA/TA & Rank & Average rank & Rank of factor \\
\hline \multicolumn{7}{|c|}{ Qatar } \\
\hline QN Bank & $15.22 \%$ & 5 & $0.43 \%$ & 5 & 5 & 5 \\
\hline Com Bank & $15.89 \%$ & 4 & $1.45 \%$ & 1 & 2.5 & 1 \\
\hline Doha Bank & $15.94 \%$ & 3 & $0.94 \%$ & 2 & 2.5 & 1 \\
\hline ABQ Bank & $15.96 \%$ & 2 & $0.73 \%$ & 3 & 2.5 & 1 \\
\hline IBQ Bank & $14.21 \%$ & 6 & $0.59 \%$ & 4 & 5 & 5 \\
\hline ALKHALIJI Bank & $28.92 \%$ & 1 & $0.33 \%$ & 6 & 3.5 & 4 \\
\hline Average & $17.69 \%$ & - & $0.75 \%$ & - & - & - \\
\hline \multicolumn{7}{|c|}{ Kuwait } \\
\hline NBK Bank & $13.08 \%$ & 1 & $1.05 \%$ & 3 & 2 & 1 \\
\hline CBK Bank & $8.48 \%$ & 2 & $0.70 \%$ & 4 & 3 & 4 \\
\hline GULF Bank & $2.17 \%$ & 5 & $0.52 \%$ & 5 & 5 & 5 \\
\hline BURGAN Bank & $7.30 \%$ & 4 & $1.23 \%$ & 1 & 2.5 & 2 \\
\hline ABK Bank & $7.50 \%$ & 3 & $1.09 \%$ & 2 & 2.5 & 2 \\
\hline Average & $7.71 \%$ & - & $0.92 \%$ & - & - & - \\
\hline Sign. level of ANOVA & $0.00 \%$ & - & $5.89 \%$ & - & - & - \\
\hline
\end{tabular}


Table 5. Average ratios of years and rankings in the case of the Management efficiency factor at selected banks

\begin{tabular}{|c|c|c|c|c|c|c|}
\hline \multirow[b]{2}{*}{ Banks } & \multicolumn{6}{|c|}{ Management efficiency } \\
\hline & NP/Staff cost & Rank & NII/PROF & Rank & $\begin{array}{c}\text { Average } \\
\text { rank }\end{array}$ & $\begin{array}{c}\text { Rank } \\
\text { of attribute }\end{array}$ \\
\hline \multicolumn{7}{|c|}{ Qatar } \\
\hline QN Bank & $481.23 \%$ & 1 & $126.12 \%$ & 4 & 2.5 & 1 \\
\hline Com Bank & $155.09 \%$ & 6 & $266.03 \%$ & 1 & 3.5 & 2 \\
\hline Doha Bank & $243.83 \%$ & 5 & $166.58 \%$ & 2 & 3.5 & 2 \\
\hline ABQ Bank & $363.63 \%$ & 2 & $123.94 \%$ & 5 & 3.5 & 2 \\
\hline IBQ Bank & $296.14 \%$ & 3 & $120.56 \%$ & 6 & 4.5 & 6 \\
\hline ALKHALIJI Bank & $259.18 \%$ & 4 & $156.17 \%$ & 3 & 3.5 & 2 \\
\hline Average & $299.85 \%$ & - & $159.90 \%$ & - & - & - \\
\hline \multicolumn{7}{|c|}{ Kuwait } \\
\hline NBK Bank & $219.42 \%$ & 1 & $150.87 \%$ & 5 & 3 & 1 \\
\hline CBK Bank & $214.13 \%$ & 2 & $211.22 \%$ & 4 & 3 & 1 \\
\hline GULF Bank & $95.59 \%$ & 5 & $312.31 \%$ & 1 & 3 & 1 \\
\hline BURGAN Bank & $122.07 \%$ & 4 & $286.00 \%$ & 2 & 3 & 1 \\
\hline ABK Bank & $132.97 \%$ & 3 & $284.43 \%$ & 3 & 3 & 1 \\
\hline Average & $156.83 \%$ & - & $248.97 \%$ & - & - & - \\
\hline Sign. level of ANOVA & $0.00 \%$ & - & $0.00 \%$ & - & - & - \\
\hline
\end{tabular}

are almost twice as much as the Kuwaiti banks, which shows considerable employment efficiency differences. There is a remarkable margin within the countries in the NP / Staff cost ratio; for instance, in Qatar, the QN bank has a three times bigger ratio value than the Com Bank. Also, a similar tendency can be observed in the case of Kuwaiti banks, but on a lower level of ratios. It can be stated that there is a significant difference between countries' averages; the average of Kuwaiti banks is only $52 \%$ of Qatari banks. This notable difference is likely because there is a statistically significant difference between the countries with a significance level of less than $0.1 \%$. The table also shows that the highest ratio value of Kuwaiti banks (NBK: 219, 42\%) is less than half of the highest ratio value of Qatari banks (QN Bank: 481.23\%).

The second ratio of this factor is Net interest income to Net profit, which also shows big differences between countries but in the opposite direction (Table 5). Here, Kuwaiti banks provide better performance than Qatari banks. It can mean that Qatari banks can achieve a higher interest income compared to their profits. Kuwaiti banks work more efficiently (248.97\%) than Qatari banks (159.90\%). The average value of Qatari banks is only $64,22 \%$ of Kuwaiti banks' value. The ANOVA test verifies this difference with a significantly high level $(<0.1 \%)$.
Table 5 also shows that the average of the rankings of the two indicators is the same for Qatari banks in four cases (4/6), while it is the same for all Kuwaiti banks (5/5). This indicates that the two indicators complement each other relatively accurately.

\subsection{Ranking banks using the Earnings quality factor}

In the Earnings quality factor of the CAMELS model, two commonly known ratios were used to measure profitability, the return on assets (ROA) and the return on equity (ROE) ratios.

As shown in Table 6, the ROA has an outlier value $(9.39 \%)$ in IBQ Bank, which is more than four times more than the following biggest ratio (QN Bank: 1.95\%). The average ROA of Qatari banks exceeds $1 \%$ in all cases, while there are only two banks in Kuwait. The ratio values of Kuwaiti banks are more balanced than Qatari banks. The average ratios of the two countries are different; the average ratio value of Qatari banks (2.80\%) is almost three times higher than Kuwaiti banks (0.98\%).

The ANOVA strengthened this big difference as it signs a significant difference between the countries based on this ratio at the significance level of less than $0.1 \%$. Examining the ROE ratio, one 
Table 6. Average ratios of years and rankings in the case of the Earnings quality factor at selected banks

\begin{tabular}{|c|c|c|c|c|c|c|}
\hline \multirow{2}{*}{ Banks } & \multicolumn{6}{|c|}{ Earnings quality } \\
\hline & ROA & Rank & ROE & Rank & Average rank & Rank of factor \\
\hline \multicolumn{7}{|c|}{ Qatar } \\
\hline QN Bank & $1.95 \%$ & 2 & $17.67 \%$ & 1 & 1.5 & 1 \\
\hline Com Bank & $1.02 \%$ & 6 & $6.88 \%$ & 5 & 5.5 & 6 \\
\hline Doha Bank & $1.55 \%$ & 4 & $9.86 \%$ & 3 & 3.5 & 3 \\
\hline ABQ Bank & $1.84 \%$ & 3 & $13.71 \%$ & 2 & 2.5 & 2 \\
\hline IBQ Bank & $9.39 \%$ & 1 & $3.73 \%$ & 6 & 3.5 & 3 \\
\hline ALKHALIJI Bank & $1.07 \%$ & 5 & $8.71 \%$ & 4 & 4.5 & 5 \\
\hline Average & $2.80 \%$ & - & $10.09 \%$ & - & - & - \\
\hline \multicolumn{7}{|c|}{ Kuwait } \\
\hline NBK Bank & $1.29 \%$ & 1 & $13.80 \%$ & 1 & 1 & 1 \\
\hline CBK Bank & $1.08 \%$ & 2 & $7.58 \%$ & 3 & 2.5 & 2 \\
\hline GULF Bank & $0.73 \%$ & 5 & $7.26 \%$ & 4 & 4.5 & 4 \\
\hline BURGAN Bank & $0.90 \%$ & 3 & $7.83 \%$ & 2 & 2.5 & 2 \\
\hline ABK Bank & $0.89 \%$ & 4 & $6.17 \%$ & 5 & 4.5 & 4 \\
\hline Average & $0.98 \%$ & - & $8.53 \%$ & - & - & - \\
\hline Sign. level of ANOVA & $0.00 \%$ & - & $0.01 \%$ & - & - & - \\
\hline
\end{tabular}

can see that there is no such big difference as the ROA ratio. However, the difference between the two countries concerning the ROE ratio is also statistically significant at less than $1 \%$ significance level. With Qatari banks, there are greater differences between the banks than in the case of Kuwaiti banks. The values of ROE ratios are not as balanced as the ROA ratios.

\subsection{Ranking banks using the Liquidity management factor}

Liquidity is an essential factor that reflects a bank's capability to fulfil its financial liabilities. Sufficient liquidity means how the banks had funds to cover the short-term liabilities. In the case of banks, the continuous maintenance of liquidity is of paramount importance as its shortage can lead to a loss of customer confidence. By the customers' deposits and converting the assets into cash, the banks can meet their obligations. Liquidity is synchronized with profitability, so the shortage in meeting the banks' financial obligations could also affect the bank's profitability and performance. Two ratios of the Liquidity management factor are Loans due to banks and Cash \& Cash equivalents to Total assets.

Table 7 shows two outliers for Qatari banks in the Loans / Due to bank ratio, significantly high- er than the other values. The table also shows that there are significant differences in the indicator values for both countries. The averages of the indicators of the two countries differ significantly (140.68); nevertheless, no statistically significant difference can be detected between the countries.

For the other ratios (Cash \& cash equivalents to Total assets), more balanced values can be found in Table 7, and the country average does not differ significantly either. In the case of the second indicator, there is no statistically significant difference between the two countries. Because of the above, it can be stated that the countries do not differ significantly in terms of the Liquidity Management factor.

\subsection{Ranking banks using the sensitivity to market factor}

Sensitivity expresses the risk of changes in market conditions, which can adversely affect a bank's profit or capital. Market risks include the risks of interest rates, foreign exchange rates, and fixed asset prices. It also reflects the extent of management's ability to identify and control these risks. This component was measured using the following financial ratios: Net interest income to Total assets and Total reserves to Total assets. 
Table 7. Average ratios of years and rankings in the case of the Liquidity management factor at selected banks

Source: Author's calculation.

\begin{tabular}{|c|c|c|c|c|c|c|}
\hline \multirow[b]{2}{*}{ Banks } & \multicolumn{6}{|c|}{ Liquidity management } \\
\hline & $\begin{array}{c}\text { Loans/Due to } \\
\text { Bank }\end{array}$ & Rank & $\begin{array}{c}\text { Cash \& Cash } \\
\text { Equivalents/TA }\end{array}$ & Rank & $\begin{array}{c}\text { Average } \\
\text { rank }\end{array}$ & $\begin{array}{c}\text { Rank of } \\
\text { factor }\end{array}$ \\
\hline \multicolumn{7}{|c|}{ Qatar } \\
\hline QN Bank & $1397.90 \%$ & 6 & $6.74 \%$ & 6 & 6.0 & 6 \\
\hline Com Bank & $597.47 \%$ & 4 & $10.29 \%$ & 4 & 4.0 & 4 \\
\hline Doha Bank & $514.22 \%$ & 3 & $11.15 \%$ & 2 & 2.5 & 3 \\
\hline ABQ Bank & $1111.12 \%$ & 5 & $9.13 \%$ & 5 & 5.0 & 5 \\
\hline IBQ Bank & $471.35 \%$ & 2 & $16.10 \%$ & 1 & 1.5 & 1 \\
\hline ALKHALIJI Bank & $234.54 \%$ & 1 & $10.53 \%$ & 3 & 2.0 & 2 \\
\hline Average & $721.10 \%$ & - & $10.66 \%$ & - & - & - \\
\hline \multicolumn{7}{|c|}{ Kuwait } \\
\hline NBK Bank & $191.75 \%$ & 1 & $12.74 \%$ & 3 & 2.0 & 1 \\
\hline CBK Bank & $751.42 \%$ & 4 & $13.11 \%$ & 2 & 3.0 & 3 \\
\hline GULF Bank & $1060.25 \%$ & 5 & $11.57 \%$ & 4 & 4.5 & 5 \\
\hline BURGAN Bank & $541.36 \%$ & 3 & $13.13 \%$ & 1 & 2.0 & 1 \\
\hline ABK Bank & $357.34 \%$ & 2 & $6.13 \%$ & 5 & 3.5 & 4 \\
\hline Average & $580.42 \%$ & - & $11.34 \%$ & - & - & - \\
\hline Sign. level of ANOVA & $22.57 \%$ & - & $44.36 \%$ & - & - & - \\
\hline
\end{tabular}

Table 8 reveals that in Qatar, Doha Bank has obtained the highest rank number in the group in the NII / TA ratio with an average value of $2.49 \%$, followed by QN Bank with 2.44\%, and ALKHALIJI Bank received the lowest rank number with $1.60 \%$. However, based on the second ratio (TR/TA), ALKHALIJI Bank comes to the top with an average value of $3.68 \%$. In comparison, IBQ Bank got to the last place, with a value of $8.03 \%$. In Kuwait, given the NII / TA ratio, ABK Bank held the first position with a value of $2.47 \%$. BURGAN Bank achieved the second position, and the NBK bank has the lowest ranking with a value of $1.95 \%$ and stood in the last position. Furthermore, GULF Bank has the highest rank number, considering the TR/TA ratio, and stayed on the top with an average value of $1.24 \%$. In comparison, ABK Bank has earned the lowest rank with an average of $7.31 \%$.

Table 8. Average ratios of years and rankings in the case of the Sensitivity factor at selected banks

Source: Author's calculation.

\begin{tabular}{|c|c|c|c|c|c|c|}
\hline \multirow{2}{*}{ Banks } & \multicolumn{6}{|c|}{ Sensitivity } \\
\hline & NII/TA & Rank & TRs/TA & Rank & Average rank & Rank of factor \\
\hline \multicolumn{7}{|c|}{ Qatar } \\
\hline QN Bank & $2.44 \%$ & 2 & $4.48 \%$ & 2 & 2 & 1 \\
\hline Com Bank & $1.97 \%$ & 4 & $8.92 \%$ & 6 & 5 & 5 \\
\hline Doha Bank & $2.49 \%$ & 1 & $6.86 \%$ & 4 & 2.5 & 2 \\
\hline ABQ Bank & $2.28 \%$ & 3 & $6.08 \%$ & 3 & 3 & 3 \\
\hline IBQ Bank & $1.94 \%$ & 5 & $8.03 \%$ & 5 & 5 & 5 \\
\hline ALKHALIJI Bank & $1.60 \%$ & 6 & $3.68 \%$ & 1 & 3.5 & 4 \\
\hline Average & $2.12 \%$ & - & $6.34 \%$ & - & - & - \\
\hline \multicolumn{7}{|c|}{ Kuwait } \\
\hline NBK Bank & $1.95 \%$ & 5 & $6.86 \%$ & 4 & 4.5 & 5 \\
\hline CBK Bank & $2.09 \%$ & 4 & $6.49 \%$ & 3 & 3.5 & 4 \\
\hline GULF Bank & $2.25 \%$ & 3 & $1.24 \%$ & 1 & 2 & 1 \\
\hline BURGAN Bank & $2.29 \%$ & 2 & $1.69 \%$ & 2 & 2 & 1 \\
\hline ABK Bank & $2.47 \%$ & 1 & $7.31 \%$ & 5 & 3 & 3 \\
\hline Average & $2.21 \%$ & - & $4.72 \%$ & - & - & - \\
\hline Sign. Level & $22.73 \%$ & - & $0.73 \%$ & - & - & - \\
\hline
\end{tabular}


Table 8 shows no statistically significant difference between the two countries for the NII / TA indicator. In contrast, for the second indicator (TRs / TA), the difference is significant at a level of less than $1 \%$.

\subsection{Summation of banks' factor rankings}

Table 9 shows the final ranking of the selected banks in Qatar and Kuwait according to their financial performance. It gives a rating of six factors of the CAMELS rating analysis separately. The total average of these six factors was calculated for each bank to present the final ranking of the banks according to their overall financial performance.

In the case of Qatar, it can be noticed that Doha Bank ranked first among all banks with a total average of 2.00, and the second-rated bank was ABQ Bank. In contrast, the other two banks ranked third (Com Bank and QN Bank) with a total average of 3.33, and IBQ ranked last with a total average of 3.83. On the other hand, at Al-Kuwait, Burgan Bank was ranked at the headmost position with a total average of 1.83 , followed by NBK with a very close average (2.00), then $A B K$ ranked third, and CBK ranked fourth. GULF bank has taken up the last position among all banks with a total average of 3.50 .

Multivariate analysis of variance (MANOVA) was used to investigate statistically significant differences between countries considering CAMELS factors. This method examines the difference between countries using two variables of a given factor together, and this investigation covered all factors.

Table 10 shows that given both variables per factor simultaneously, i.e. examined per factor, countries differ statistically significantly on at least a 5\% significance level for four factors: Asset quality, Management efficiency, Earnings quality and Sensitivity to market. It can be seen from Table 10 that for two factors (Capital adequacy and Liquidity management), there is no statistically significant difference between the countries.

\subsection{Evaluation of hypotheses}

Using the results presented in Section 3, the three hypotheses formulated at the beginning of the study are evaluated.

1. Statistically significant differences between the countries can be determined for all the financial ratios.

Evaluating the analysis of variance results, it can be concluded that it shows a very mixed picture. Examining the 12 indicators, one can state that there is a statistically significant difference between the countries at the significance level of at least $5 \%$ in the case of six ratios. A case where both indicators of a factor indicated significant differences between the countries occurred for two factors: Management efficiency and Earnings quality.

Table 9. The overall ranking of the selected banks from Qatar and Kuwait for the period 2013-2017

\begin{tabular}{|c|c|c|c|c|c|c|c|c|}
\hline Banks & $\begin{array}{c}\text { Capital } \\
\text { adequacy }\end{array}$ & $\begin{array}{c}\text { Asset } \\
\text { quality }\end{array}$ & $\begin{array}{c}\text { Management } \\
\text { efficiency }\end{array}$ & $\begin{array}{l}\text { Earnings } \\
\text { quality }\end{array}$ & $\begin{array}{c}\text { Liquidity } \\
\text { management }\end{array}$ & Sensitivity & $\begin{array}{c}\text { Total } \\
\text { average }\end{array}$ & $\begin{array}{l}\text { Total } \\
\text { rank }\end{array}$ \\
\hline \multicolumn{9}{|c|}{ Qatar } \\
\hline QN Bank & 6 & 5 & 1 & 1 & 6 & 1 & 3.33 & 3 \\
\hline Com Bank & 2 & 1 & 2 & 6 & 4 & 5 & 3.33 & 3 \\
\hline Doha Bank & 1 & 1 & 2 & 3 & 3 & 2 & 2.00 & 1 \\
\hline ABQ Bank & 5 & 1 & 2 & 2 & 5 & 3 & 3.00 & 2 \\
\hline IBQ Bank & 3 & 5 & 6 & 3 & 1 & 5 & 3.83 & 6 \\
\hline ALKHALIJI Bank & 4 & 4 & 2 & 5 & 2 & 4 & 3.50 & 5 \\
\hline \multicolumn{9}{|c|}{ Kuwait } \\
\hline NBK Bank & 3 & 1 & 1 & 1 & 1 & 5 & 2.00 & 2 \\
\hline CBK Bank & 2 & 4 & 1 & 2 & 3 & 4 & 2.67 & 4 \\
\hline GULF Bank & 5 & 5 & 1 & 4 & 5 & 1 & 3.50 & 5 \\
\hline BURGAN Bank & 4 & 2 & 1 & 2 & 1 & 1 & 1.83 & 1 \\
\hline ABK Bank & 1 & 2 & 1 & 4 & 4 & 3 & 2.50 & 3 \\
\hline
\end{tabular}


Table 10. The result of multivariate analysis of variance comparing the banks' attributes in two countries

Source: Author's calculation.

\begin{tabular}{|c|c|c|c|}
\hline \multirow{2}{*}{ Factor names } & \multicolumn{2}{|c|}{ Countries } & \multirow{2}{*}{ Significance level } \\
\hline & Qatar & Kuwait & \\
\hline \multirow{2}{*}{ Capital adequacy } & $13.55 \%$ & $12.75 \%$ & \multirow{2}{*}{$13.83 \%$} \\
\hline & $19.06 \%$ & $14.68 \%$ & \\
\hline \multirow{2}{*}{ Asset quality } & $17.69 \%$ & $7.71 \%$ & \multirow{2}{*}{$0.00 \%$} \\
\hline & $0.75 \%$ & $0.92 \%$ & \\
\hline \multirow{2}{*}{ Management efficiency } & 299.85 & 156.837 & \multirow{2}{*}{$0.00 \%$} \\
\hline & 159.90 & 248.97 & \\
\hline \multirow{2}{*}{ Earnings quality } & $2.80 \%$ & $0.98 \%$ & \multirow{2}{*}{$0.00 \%$} \\
\hline & $10.09 \%$ & $8.53 \%$ & \\
\hline \multirow{2}{*}{ Liquidity management } & 721.10 & 580.42 & \multirow{2}{*}{$43.18 \%$} \\
\hline & $10.66 \%$ & $11.34 \%$ & \\
\hline Sensitivity to market & $2.12 \%$ & $2.21 \%$ & $1.33 \%$ \\
\hline
\end{tabular}

There was only a significant difference for one ratio in the Asset quality and Sensitivity to market factors. Of the six significantly different indicators, Qatari banks' averages were better in five cases, and Kuwaiti in only one case. If the significance level threshold was reduced to $10 \%$, a significant difference could be detected for eight indicators. In that case, the ratio distribution between the countries would be 6: 2 in favor of Qatar.

Given the above, it can be concluded that this hypothesis was only partially fulfilled, as significant differences can be determined between the countries based on the CAMELS indicators in six cases.

2. Statistically significant differences between the two countries can be determined based on CAMELS factors.
Based on the MANOVA test, it can be stated that in four of the six factors, there is a significant difference between the countries. As this ratio represents $2 / 3$ of the factors, one can state that the countries differ significantly in terms of the factors.

This hypothesis is acceptable.

3. Based on the analysis performed, obvious differences can be identified for the banks of the two countries.

Considering the description of the first two hypotheses, it can be stated that the overall performance of the banks of the two countries may differ significantly. It can also be seen that, on average, Qatari banks performed better.

\section{CONCLUSION}

The fundamental aim of the study was to compare the performance of selected banks in two countries, Kuwait and Qatar, within and between countries. The ratios of the CAMELS model were used to compare banks.

Comparing the banks of the two countries by financial ratios, it can be stated that there is a statistically significant difference between them in six cases. In five of the statistically significant cases, Kuwaiti banks performed better on average. Based on these, it can be concluded that Kuwaiti banks performed better than Qatari banks, considering the variables examined. There are two factors for which there is no statistically significant difference between the banks of the two countries for either financial indicator: Capital adequacy and Liquidity management. This may be because these factors are among the most basic conditions for banking. Therefore, all banks pay much more attention to these.

Comparisons made using the two financial ratios of factors yielded similar results in terms of significance levels as in the comparisons per ratio. There was also no statistically significant difference between the Capital adequacy and Liquidity management factors in this case. However, when the two indicators 
were examined together, except for the Earnings quality factor, banks in one country performed better in one ratio, and banks in another country in the other ratio. There was also no statistically significant difference between the Capital adequacy and Liquidity management factors in this case. In the case of the Earnings quality factor, Qatari banks performed better for both ratios. In this analysis, Qatari banks performed better in five cases of the eight ratios. Thus, when examining the factors, it can already be concluded that Qatari banks perform better.

Due to the above, it can be concluded that it is useful to examine the factors' effects because they show the effect of the two ratios together, and thus, they can show a more evaluable picture of performance.

Based on the final ranking of the CAMELS model, it can be concluded that their range is slightly narrower for Kuwaiti banks (1.67) than for Qatari banks (1.83). This means that the performance of Kuwaiti banks is slightly more balanced than that of Qatari banks. This is supported by the fact that the average score in the first place is 1.83 for Kuwaiti banks and 2 for Qatari banks.

Kuwaiti banks should increase labor efficiency and improve return on assets. Considering all the factors of CAMELS, Kuwaiti banks would have to think through how they could achieve the performance of Qatari banks. It would be advisable for Qatari banks to increase their return on assets and improve the efficiency of bank management. In the future, it would be useful to perform an analysis to identify the factors that have a significant impact on the development of bank profitability and performance in the two countries.

\section{AUTHOR CONTRIBUTIONS}

Conceptualization: Rawan Abuzarqa, Tibor Tarnoczi.

Data curation: Rawan Abuzarqa.

Formal analysis: Rawan Abuzarqa, Tibor Tarnoczi.

Funding acquisition: Rawan Abuzarqa.

Investigation: Rawan Abuzarqa.

Methodology: Rawan Abuzarqa.

Project administration: Rawan Abuzarqa, Tibor Tarnoczi.

Resources: Rawan Abuzarqa.

Supervision: Tibor Tarnoczi.

Validation: Rawan Abuzarqa.

Visualization: Rawan Abuzarqa, Tibor Tarnoczi.

Writing - original draft: Rawan Abuzarqa.

Writing - reviewing \& editing: Tibor Tarnoczi.

\section{REFERENCES}

1. Abdmoulah, W., \& Laabas, B. (2012). Kuwaiti banks efficiency: An examination of technical and allocative efficiency over the period 1994-2009. International Review of Business Research Papers, 8(5), 123-136. Retrieved from https://paperzz.com/doc/7066724/ kuwaiti-banks-efficiency--anexamination-of-technical-and

2. Abdul-Wahab, A.-H., \& Haron, R. (2017). Efficiency of the Qatari banking industry: an empirical investigation. International
Journal of Bank Marketing, 35(2), 298-318. https://doi.org/10.1108/ IJBM-07-2016-0090

3. Altan, M., Yusufazari, H., \& Bedük, A. (2014). Performance Analysis of Banks in Turkey Using CAMEL Approach. In Proceedings of International Academic Conferences (No. 0902916). International Institute of Social and Economic Sciences. Retrieved from https://ideas.repec.org/p/sek/ iacpro/0902916.html
4. Arab Bankers Association (ABA). (2019). National Bank of Kuwait: a bank for the next generation. Arab Banker, 30, 12-15. Retrieved from https://www.arab-bankers. co.uk/img/db/magazine-pdf/ABA ArabBanker_Full_270719.pdf

5. Baral, K. J. (2005). Health checkup of commercial banks in the framework of CAMEL: A case study of joint venture banks in Nepal. Journal of Nepalese Business Studies, 2(1), 41-55. http://dx.doi. org/10.3126/jnbs.v2i1.55 
6. Barker, D., \& Holdsworth, D. (1993). The causes of bank failures in the 1980s (Research Paper No. 9325). Federal Reserve Bank of New York. Retrieved from https:// ideas.repec.org/p/fip/fednrp/9325. html

7. Barr, R. S., Killgo, K. A., Siems, T. F., \& Zimmel, S. (2002). Evaluating the productive efficiency and performance of US commercial banks. Managerial Finance, 28(8), 3-25. https://doi. org/10.1108/03074350210767988

8. Bodla, B. S., \& Verma, R. (2006). Evaluating performance of banks through CAMEL Model: A case study of SBI and ICIC. The IUP Journal of Bank Management, 5(3), 49-63. Retrieved from https:// econpapers.repec.org/article/ icficfjbm/v_3a5_3ay_3a2006_3ai_ 3a3_3ap_3a49-63.htm

9. Chandani, A., Mehta, M., \& Chandrasekaran, K. B. (2014). A Working Paper on the Impact of Gender of Leader on the Financial Performance of the Bank: A Case of ICICI Bank. Procedia Economics and Finance, 11, 459-471. https://doi.org/10.1016/S22125671(14)00212-3

10. Dincer, H., Gencer, G., Orhan, N., \& Sahinbas, K. (2011). A performance evaluation of the Turkish banking sector after the global crisis via CAMELS ratios. Procedia-Social and Behavioral Sciences, 24, 1530-1545. https://doi. org/10.1016/j.sbspro.2011.09.051

11. Echekoba, F. N., Egbunike, C. F., \& Kasie, E. G. (2014). Determinants of Bank Profitability in Nigeria: Using Camel Rating Model (20012010). Journal of Business and Management, 16(9), 44-50. https:// doi.org/10.9790/487X-16964450

12. Gasbarro, D., Sadguna, I. G. M., Zumwalt, J. K. (2002). The changing relationship between CAMEL ratings and bank soundness during the Indonesian banking crisis. Review of Quantitative Finance and Accounting, 19(3), 247-260. http://dx.doi. org/10.1023/A:1020724907031

13. Ghazavi, M., \& Bayraktar, S. (2018). Performance Analysis of
Banks in Turkey Using Camels Approach Case Study: Six Turkish Banks During 2005 To 2016. İşletme Araştrımaları Dergisi, 10(2), 847-874. http://dx.doi. org/10.20491/isarder.2018.458

14. International Monetary Fund (IMF). (2019). Qatar: 2019 Article IV Consultation-Press Release (Staff Report). Retrieved from https://www.imf.org/en/Publications/CR/Issues/2019/06/02/ Qatar-2019-Article-IV$\%$ E2\%80\%8EConsultation-PressRelease-Staff-Report-46956

15. Joshi, A., \& Sharma, L. D. (2015). Seeking the Best Indian Bank: An Implementation to Camel Model. International Journal of Applied Financial Management Perspectives 3(4), 1349-1358. Retrieved from https://www.academia. edu/18618586/SEEKING_THE_ BEST_INDIAN_BANK_AN_IMPLEMENTATION_TO_CAMEL_ MODEL

16. Kumar, S., \& Sharma, R. (2014). Performance analysis of top Indian Banks through camel approach. International Journal of Advanced Research in Management and Social Sciences, 3(7), 81-92. Retrieved from https://www. semanticscholar.org/paper/Performance-analysis-of-top-IndianBanks-through-Kumar-Sharma/4 0481f447fce46c17a281ce9c08dee5 601e30053

17. Nanthini, V., \& Shanmugam, N. K. (2020). A Study On Financial Performance of Private Sectors Banks in India - A Camel Model. Turkish Journal of Physiotherapy and Rehabilitation, 32(2), 19371940. Retrieved from https://www. turkjphysiotherrehabil.org/pub/ pdf/322/32-2-250.pdf

18. Nguyen, A. H., Nguyen, H. T., \& Pham, H. T. (2020). Applying The Camel Model to Assess Performance of Commercial Banks: Empirical Evidence from Vietnam. Banks and Bank Systems, 15(2), 177-186. http://dx.doi. org/10.21511/bbs.15(2).2020.16

19. Qatar Central Bank (QCB). (2020). Monetary System in Qatar Historical Background. Retrieved from http://www.qcb.gov.qa/english/aboutqcb/pages/history.aspx

20. Roman, A., \& Şargu, A. C. (2013). Analyzing the financial soundness of the commercial banks in Romania: An approach based on the camels framework. Procedia Economics and Finance, 6, 703-712. https://doi.org/10.1016/S22125671(13)00192-5

21. Rose, P., \& Hudgins, S. (2010). Bank Management and Financial Services (8th ed.). McGraw Hill/ Irwin.

22. Saikrishna, M. B., \& Varghese, A. (2020). A Camel Model Analysis of Selected Public (Sbi) And Private (Hdfc) Sector Banks In India. Studies in Indian Place Names, 40(3), 2145-2152.

23. Suresh, C., \& Bardastani, M. (2016). Financial Performance of Selected Conventional And Islamic Banks In Kingdom of Bahrain - A CAMEL Ranking Based Approach. European Journal of Contemporary Economics and Management, 1(1), 23-59. Retrieved from http:// elpjournal.eu/wp-content/uploads/2016/07/Vol.1.No_.1.2.pdf

24. Thagunna, K., \& Poudel, S. (2013). Measuring Bank Performance of Nepali Banks: A Data Envelopment Analysis (DEA) Perspective. International Journal of Economics and Financial Issues, 3(1), 54-65. Retrieved from https:// www.semanticscholar.org/paper/ Measuring-Bank-Performanceof-Nepali-Banks\%3A-A-DataThagunna-Poudel/86fc089a7c0bcd cfe17871fd2f941e3345c64ba5

25. Union of Arab Banks. (2020). Official site. https://uabonline.org/

26. Venkatesh, D., \& Suresh, C. (2014). Comparative Performance Evaluation of Selected Commercial Banks in Kingdom of Bahrain Using CAMELS Method. https:// doi.org/10.2139/ssrn.2418144

27. Yuksel, S., Dincer, H., \& Hacioglu, U. (2015). CAMELS-based Determinants for the Credit Rating of Turkish Deposit Banks. International Journal of Finance \& Banking Studies, 4(4), 1-17. https:// doi.org/10.20525/ijfbs.v4i4.35 